(c) American Dairy Science Association, 2003.

\title{
Excretion of Aflatoxin M1 in Milk of Dairy Ewes Treated with Different Doses of Aflatoxin B1
}

\author{
G. Battacone, ${ }^{*}$ A. Nudda,* A. Cannas, ${ }^{*}$ A. Cappio Borlino,, G. Bomboi,† and G. Pulina* \\ *Dipartimento di Scienze Zootecniche, Università degli Studi di Sassari, \\ Via E. De Nicola 9, 07100 Sassari, Italy \\ †Dipartimento di Biologia Animale, Università degli Studi di Sassari, \\ Via Vienna 2, 07100 Sassari, Italy
}

\begin{abstract}
Two experiments were conducted to study the amount of aflatoxin M1 (AFM1) in milk in response to feeding aflatoxin B1 (AFB1). In experiment 1, four dairy ewes in early lactation received a single dose of pure AFB1 (2 mg). Individual milk samples were collected during the following $5 \mathrm{~d}$ to measure AFM1 concentration. The average excretion of AFM1 in milk followed an exponential decreasing pattern, with two intermediate peaks at 24 and $48 \mathrm{~h}$. No AFM1 was detected in milk at $96 \mathrm{~h}$ after dosing. The mean rate of transfer of AFB1 into AFM1 in milk was $0.032 \%$, with a high individual variability $(\mathrm{SD}=0.017 \%)$.
\end{abstract}

In experiment 2,16 dairy ewes in midlactation were divided into four groups that received different daily doses of AFB1 $(0,32,64$, and $128 \mu \mathrm{g}$ for control and groups T1, T2, and T3, respectively) for $14 \mathrm{~d}$. Pure AFB1 was administered to each animal divided in two daily doses. Individual milk samples were collected at 12,24 , $36,48,72,96,144,216$, and $312 \mathrm{~h}$ after the first AFB1 administration, during the intoxication period, and every $24 \mathrm{~h}$ for $7 \mathrm{~d}$ after the withdrawal of AFB1. AFM1 was detected in the milk of all animals of the treated groups at $12 \mathrm{~h}$ after the administration of AFB1. In all treated groups, milk AFM1 concentration increased from 12 to $144 \mathrm{~h}$ after the beginning of administration. It then decreased, reaching a stable concentration at 216 and $312 \mathrm{~h}$ after the first administration. No AFM1 was detected in milk $3 \mathrm{~d}$ after the last administration of AFB1. Milk AFM1 concentration measured at steadystate condition was significantly affected by the AFB1 dose $(0.031,0.095$, and 0.166 in $\mathrm{T} 1, \mathrm{~T} 2$, and $\mathrm{T} 3$ groups, respectively), with a linear relationship between AFB1 dose and milk AFM1 concentration $\left(\mathrm{R}^{2}=77.2 \%\right)$. The carryover (AFM1/AFB1 ratio) was not significantly affected by treatment, and its mean value was $0.112 \%$ (SE $=0.011$ ). The carryover was lower than that reported for

Received July 4, 2002.

Accepted February 18, 2003.

Corresponding author: G. Pulina; e-mail: gpulina@ssmain.uniss.it. dairy cattle and goats, suggesting a better ability of sheep to degrade AFB1.

(Key words: aflatoxin, dairy sheep, carryover, milk)

Abbreviation key: $\mathbf{A F}=$ aflatoxin, $\mathbf{A L P}=$ alkaline phosphatase, GOT = glutamic oxlacetic transaminase, GPT = glutamic pyruvic transaminase, HCT = hematocrit, HGB = hemoglobin, $\mathbf{M C H}=$ mean corpuscular hemoglobin, MCHC = mean corpuscular hemoglobin concentration, $\mathbf{M C V}=$ mean corpuscular volume, $\mathbf{R B C}=$ red blood cell count, TMC = total microbial count, $\mathbf{W B C}$ $=$ white blood cell count.

\section{INTRODUCTION}

Aflatoxin B1 (AFB1) is a mycotoxin produced by strains of Aspergillus flavus and Aspergillus parasiticus that grow in many animal feeds. Carcinogenic, mutagenic, and teratogenic effects of AFB1 have been reported for several animal species, including humans (Sabbioni and Sepai, 1998). For this reason, this toxin has been included in category $1 \mathrm{~A}$ of active carcinogenic compounds (IARC, 1993). Lactating animals that eat feed contaminated by AFB1 excrete in milk the aflatoxin M1 (AFM1), a metabolite of AFB1 considered a potential carcinogenic compound for humans and included in the class 2B by IARC (1993). The European Community has fixed at $0.05 \mu \mathrm{g} / \mathrm{kg}$ [Commission Regulation (EC) N. 466/2001] the limit for AFM1 in milk and at $0.05 \mathrm{mg} / \mathrm{kg}$ (Council Directive 1999/29/EC) the limit for AFB1 in feeds. The action level for AFM1 in milk and dairy products in the United States is tenfold higher $(0.50 \mu \mathrm{g} / \mathrm{kg})$ than the current level in the EC. The relationship between the amount of AFB1 ingested and quantity of AFM1 in milk is quite variable. In some cases, the intake by dairy cows of AFB1 below the tolerance level led to excretion of AFM1in milk above the EC tolerance limit (Frobish et al., 1986; Veldman et al., 1992). While for lactating cows a large literature exists, in the case of lactating sheep there is very little information on the transfer of AFM1 into milk. Indeed, the AFB1 transferred as AFM1 to milk was measured only 
by Nabney et al. (1967), who gave a high $(1 \mathrm{mg} / \mathrm{kg}$ of $\mathrm{BW}$ ) single dose of mixed aflatoxins to only one animal.

Because the AFM1 is associated with milk protein, its concentration in cheese is 3 to 4 times higher than in milk (Kiermeier and Buchner, 1977). Therefore, the study of the contamination of sheep milk by aflatoxins is particularly important because the majority of the sheep milk produced is processed into cheese (Pulina and Furesi, 2001) and because sheep milk has a higher protein concentration than cows' milk. The presence of AFM1 in commercial sheep cheese was recently reported by Minervini et al. (2000), with values between 0.050 and $0.210 \mu \mathrm{g} / \mathrm{kg}$, well above EC limits.

Because of the limited knowledge on the carryover of AFB1 in the milk of sheep, two experiments were conducted to: 1) study the relationship between AFB1 intake and AFM1 excretion in ewes treated with a single dose or continuous dosing; 2) study the effect of continuous dosing of AFB1 on metabolic and health status and on milk production of the animals.

\section{MATERIALS AND METHODS}

\section{Experiment 1}

Four multiparous Sarda ewes in early lactation (average 50 DIM) were used. Daily milk yield and BW averaged $1.7 \pm 0.37$ and $43.5 \pm 6.57 \mathrm{~kg}$ (mean $\pm \mathrm{SD}$ ). Each animal received $2 \mathrm{mg}$ of AFB1 in a single dose, per os, after the morning milking of the 1st day of the experimental period. The experiment was conducted in accordance with the guidelines of the Council Directive of EC (86/609/EEC).

Pure AFB1 (SIGMA, A-6636, Sigma Chemical Co, St. Louis, MO) was dissolved in methanol, and dry corn meal was used as the carrier for aflatoxin. Ewes were fed grass hay plus a supplement of $200 \mathrm{~g} / \mathrm{d}$ per ewe of whole-wheat grain at each milking. After the AFB1 administration, the ewes were milked for $5 \mathrm{~d}$; in the first $2 \mathrm{~d}$ the animals were milked every $6 \mathrm{~h}$ (4 times a day), whereas in the remaining $3 \mathrm{~d}$ they were milked every $12 \mathrm{~h}$ (twice a day). Individual milk yield was recorded at each milking, and individual milk samples were collected at $0,6,12,18,24,36,48,60,72,96 \mathrm{~h}$ from the administration of AFB1. Milk samples were stored at $-18^{\circ} \mathrm{C}$ until the analyses for AFM1 were performed. During the experimental period, the health of the animals was monitored continuously.

Extraction of AFM1. The extraction of AFM1 from milk was done using an immunoaffinity technique and the concentration was determined by HPLC. Fifty milliliters of defatted milk was filtered with Whatman 41 filter paper and passed through a immunoaffinity column (Ridascreen Aflatoxin $\mathrm{M}_{1}$, R-Biopharm, Germany). The column was washed with deionized water and then dried under nitrogen; the toxin was collected with $5 \mathrm{ml}$ of acetonitrile into silanized vials. Elutes from each column containing the analytes were carefully evaporated to dryness under nitrogen and redissolved in methanol and deionized water (250 and $250 \mu \mathrm{l}$, respectively).

Chromatography. The AFM1 was separated on Hewlett Packard 1100 HPLC chromatograph, connected to a reverse-phase C18 column (Merck, 5- $\mu \mathrm{m}$ particle size, $250 \times 4 \mathrm{~mm}$ i.d.), equipped with a Hewlett Packard 1100 fluorescence detector with excitation at $366 \mathrm{~nm}$ and emission at $416 \mathrm{~nm}$. The initial mobile phase was made of methanol and water in the ratio $0: 100(\mathrm{vol} / \mathrm{vol})$, then methanol was raised to $90: 10$ in $20 \mathrm{~min}$ and the flow rate was $1 \mathrm{ml} / \mathrm{min}$. Standard AFM1 (SIGMA, A-6428, Sigma Chemical Co, St. Louis, MO) was dissolved in methanol-water (50:50, vol/vol) to prepare a series of working solutions containing 0.015$0.240 \mathrm{ng}$ of AFM1/ml. Calibration curve was prepared by plotting the peak area for each standard against the quantity of AFM1 injected. The equation of calibration curve was used to compute the AFM1 content in sample extracts.

\section{Statistical Analyses}

Time evolution was modeled by regression of AFM1 excretion in milk ( $\mu \mathrm{g} / \mathrm{kg})$ over time (h). The percentage of AFB1 excreted in milk as AFM1 was calculated as the ratio between the total output of AFM1 in milk (sum of AFM1 excreted at each milking) and the total AFB1 administered, separately for each ewe. For this purpose, the AFM1 concentration at 30,42 , and $84 \mathrm{~h}$ was estimated, separately for each ewe, by regression of AFM1 over time.

\section{Experiment 2}

Sixteen multiparous Sarda ewes in late lactation (average 150 DIM) were used. Daily milk yield and BW averaged $0.8 \pm 0.16 \mathrm{~kg}$ and $40.2 \pm 3.58 \mathrm{~kg}$ (mean $\pm \mathrm{SD}$ ). Before the experiment started and during the experimental period the health of animals was monitored continuously. The ewes were milked twice a day at 7:30 a.m. and 6:30 p.m. and fed $1.5 \mathrm{~kg} / \mathrm{d}$ per head of pelleted concentrate plus grass hay ad libitum.

After a 7-d adaptation period, ewes were divided into four groups of four animals each. The control group (C) received an aflatoxin-free diet. The treated groups $(\mathrm{T})$ received the same diet of the $\mathrm{C}$ group but immediately before each milking they also were fed per os a pellet artificially contaminated by AFB1. The treated groups received for $14 \mathrm{~d}$ (intoxication period) 32 (T1), 64 (T2), and $128 \mu \mathrm{g}$ (T3) of AFB1/d per head, subdivided in two 
equal daily doses. At the end of the intoxication period $(312 \mathrm{~h})$, the aflatoxin was removed from the diet, and the ewes were monitored for another week (clearance period). Animal experimentation was conducted in accordance with the guidelines of the Council Directive of EC (86/609/EEC).

Pure AFB1 was dissolved in methanol and a concentrate pellet was used as the carrier for aflatoxin (SIGMA, A-6636, Sigma Chemical Co, St. Louis, MO). Milk yield of each ewe was recorded at each milking during the preliminary, intoxication, and clearance periods.

Individual milk samples were collected for $3 \mathrm{~d}$ before the first AFB1 administration, at 12, 24, 36, 48, 72, 96, 144,216 , and $312 \mathrm{~h}$ during the intoxication period and every $24 \mathrm{~h}$ during the clearance period. The samples were stored at $-18^{\circ} \mathrm{C}$ until analyses of AFM1 content. Milk concentration of AFM1 was determined as described in experiment 1.

Milk samples were analyzed weekly for fat, protein (N $\times 6.38$ ), and lactose with a Milkoscan 605 (Foss Electric, Hillerød, Denmark), for SCC with a Fossomatic 360 (Foss Electric) and for total microbial count (TMC) with a Bactoscan 8000 (Foss Electric).

Body weights of ewes were measured weekly. Blood samples were collected from each ewe by jugular venipuncture at weekly intervals for immediate analyses. Serum samples were analyzed (Photometer 4010 Boehringer Mannheim, Germany) with colorimetric commercial kits (Roche Diagnostics, Mannheim, Germany) for total bilirubin, direct bilirubin, total protein, urea (urea N/0.4665), glutamic pyruvic transaminase (GPT), glutamic oxlacetic transaminase (GOT), alkaline phosphatase (ALP), cholesterol, glucose, albumin, calcium, and phosphorus. Hemoglobin (HGB), hematocrit (HCT), red blood cell count (RBC), white blood cell count (WBC), mean corpuscular volume (MCV), mean corpuscular hemoglobin (MCH), and mean corpuscular hemoglobin concentration (MCHC), were determined with a Baker System instrument (9120 AX, Biochem Immunosystems Italy).

The data were analyzed with the following mixed linear model:

$$
\mathrm{y}_{\mathrm{ijk}}=\mu+\mathrm{T}_{\mathrm{i}}+\mathrm{P}_{\mathrm{j}}+(\mathrm{T} \times \mathrm{P})_{\mathrm{ij}}+\mathrm{E}_{\mathrm{k}}+\varepsilon_{\mathrm{ijk}}
$$

where:

$\mathrm{y}=$ dependent variable (AFM1 concentration, carryover, milk yield and composition, BW, blood parameters); $\mu$ = overall mean; $\mathrm{T}_{\mathrm{i}}=$ fixed effect of AFB1 administered $(\mathrm{i}=0,32,64,128 \mu \mathrm{g}) ; \mathrm{P}_{\mathrm{j}}=$ fixed effect of sampling time $(\mathrm{j}=\mathrm{h}) ; \mathrm{E}_{\mathrm{k}}=$ random effect of ewe; $\varepsilon_{\mathrm{ijk}}=$ residual error. Milk yield and its composition, and blood compo-

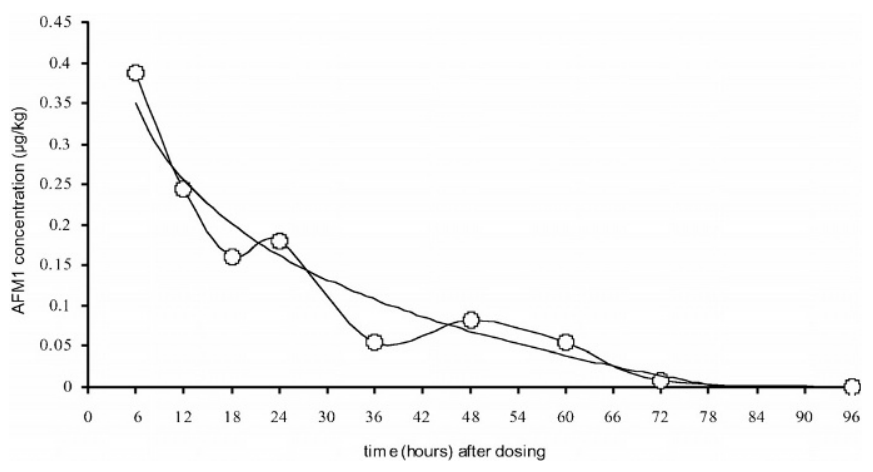

Figure 1. Average excretion pattern of AFM1 in milk of ewes fed a single oral dose of AFB1.

nents of the preexperimental week were included in the model as covariates. Before statistical analysis, SCC was natural log transformed.

The carryover was calculated, separately for each ewe, as the ratio between the AFM1 in milk and the intake of AFB1 at the time in which a steady-state output of toxin in milk was reached (216 and $312 \mathrm{~h}$ ). Finally, a regression analysis of AFM1 milk concentration on AFB1 intake was carried out.

\section{RESULTS AND DISCUSSION}

\section{Experiment 1}

The average BW of the ewes during the experimental period was $43.5 \pm 6.57 \mathrm{~kg}$, therefore each animal received $46.9 \pm 8.30 \mu \mathrm{g}$ of AFB1 per kilogram of BW. No traces of AFM1 were detected in the milk sampled before AFB1 administration. The presence of AFM1 was detected in all ewes from the first milking at $12 \mathrm{~h}$ after the AFB1 administration, in agreement with previous observations in sheep (Nabney et al., 1967) and cows (Allcroft et al., 1968; Trucksess et al., 1983) that received a single dose of AFB1. The average excretion of AFM1 in milk ( $\mu \mathrm{g} / \mathrm{kg})$ was represented by the following exponential decreasing function:

$$
\mathrm{AFM} 1=0.47 \exp \left(-0.0474^{*} \mathrm{~h}\right)\left(\mathrm{R}^{2}=0.84\right)
$$

From the excretion pattern of AFM1 (Figure 1), the maximum concentration occurred in the samples collected at first milking after dosing. Superimposed on this trend was an oscillatory pattern, particularly evident in the ewes 2 and 3, with two peaks around the 24th and the 48th $\mathrm{h}$ after dosing was observed (Figure 2). Nabney et al. (1967), using a much higher dose of aflatoxin $(1 \mathrm{mg} / \mathrm{kg} \mathrm{BW}$ of mixed $\mathrm{AF})$ than that used in our experiment, detected only one peak around 96th 

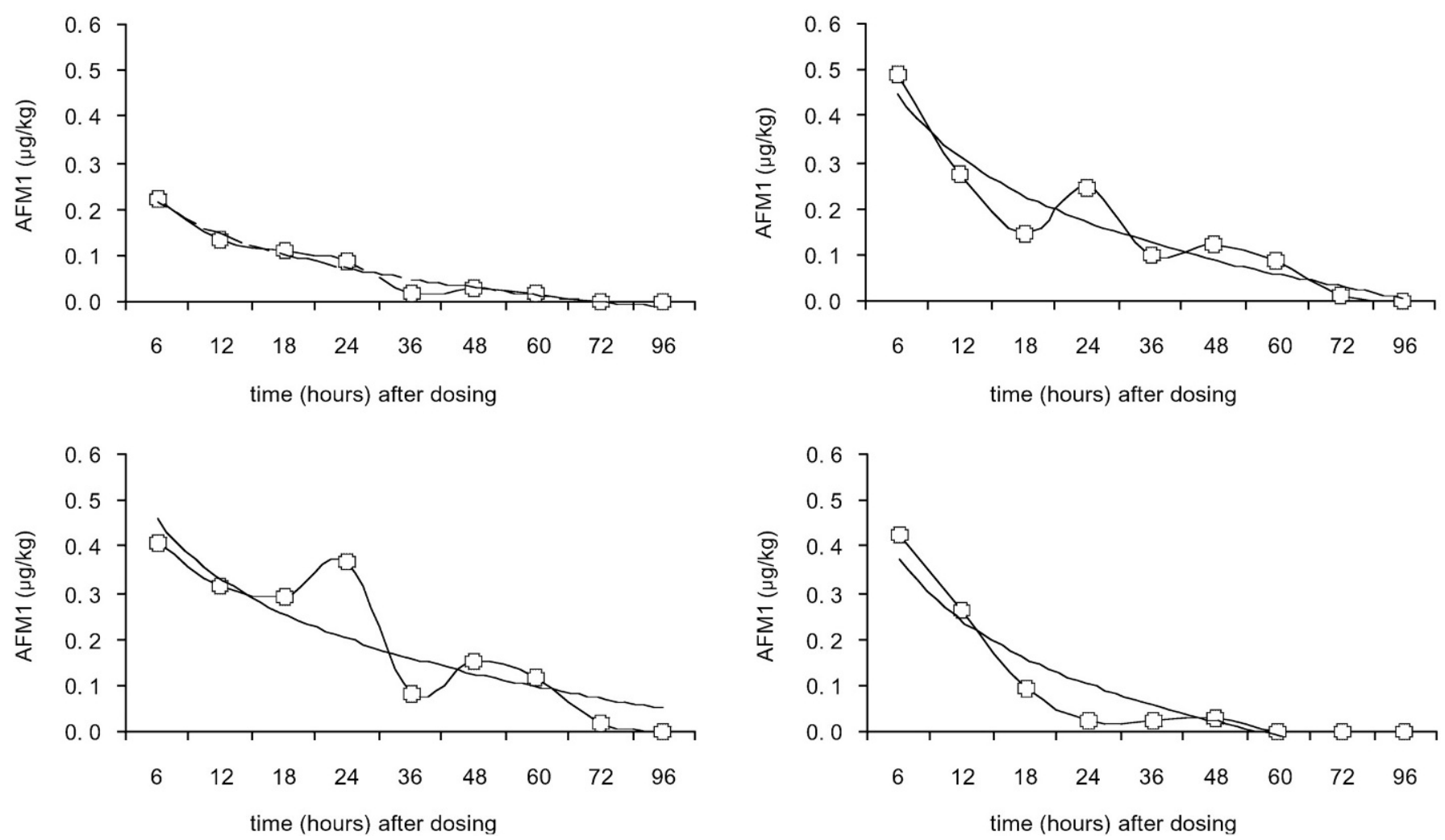

Figure 2. Individual excretion pattern of AFM1 in milk of ewes fed with a single oral dose of AFB1 (Experiment 1).

hour after dosing. An oscillatory pattern similar to that observed in our trial was previously reported in cows (Trucksess et al., 1983) using a single dose equivalent to $0.5 \mathrm{mg} / \mathrm{kg}$ BW of AFB1. The oscillatory pattern of the toxin in the milk observed may be related to variations in rumen activity, to the gradual release of the toxin from tissue to the blood, to the liver conversion rate of AFB1 to AFM1, and to the toxin excreted in urine and feces.

No AFM1 was detected in milk collected at 60,72 , 84 , and $96 \mathrm{~h}$ after dosing in ewes number $4,1,2$, and 3 , respectively (Figure 2 ). In our experiment, the clearance of toxin in milk was faster than that reported in previous studies with sheep (Nabney et al., 1967) and cows (Allcroft et al., 1968; Trucksess et al., 1983) in which a single dose was used. This result can be explained by the higher single dose of toxin administered to cows $(0.5 \mathrm{mg} / \mathrm{kg}$ of BW; Allcroft et al., 1968; Trucksess et al., 1983) and sheep (1 mg/kg of BW; Nabney et al., 1967) compared with our experiment $(46.95 \mu \mathrm{g} / \mathrm{kg}$ of BW). The dose used by Nabney et al. (1967) was near to the $\mathrm{DL}_{50}$ of AF for sheep (Armbrecht et al., 1970).

The average total milk yield in $96 \mathrm{~h}$ (Table 1) was $4.77 \pm 0.56 \mathrm{~kg}$ (mean $\pm \mathrm{SD}$ ). Total output of AFM1 in milk was $0.64 \pm 0.33 \mu \mathrm{g}$. The average amount of AFM1 excreted at 12 and $24 \mathrm{~h}$ after dosing was about 52 and $71 \%$, of the total output of toxin.

The mean ratio of AFM1 to AFB1 was 0.032\%, with a high individual variability. This ratio is markedly lower than that previously observed in a lactating ewe (0.25\%; Nabney et al., 1967) and in dairy cows $(0.35 \%$; Allcroft et al., 1968), which received single doses of AF.

\section{Experiment 2}

No AFM1 was detected in the milk of the control group. The pattern of AFM1 concentration in milk of T1, T2, and T3 groups is reported in Figure 3. The toxin was detected in the milk of all animals of the treated groups since the first milking, which occurred $6 \mathrm{~h}$ after the beginning of AFB1 administration. The passage of the toxin from feed to milk was very rapid, as previously observed in cows that received AFB1 for $8 \mathrm{~d}$ (Frobish et al., 1986). During the intoxication period, in all treated groups the milk AFM1 concentration increased from 0 to $144 \mathrm{~h}(0.057,0.226$ and $0.331 \mu \mathrm{g} / \mathrm{kg}$, in $\mathrm{T} 1, \mathrm{~T} 2$, and T3, respectively). Then, AFM1 concentration decreased and reached a steady-state condition in the interval between 216 and $312 \mathrm{~h}$. Finally, in the clearance period, AFM1 quickly decreased, and it was no longer detected 
Table 1. Total output of milk, total output of AFM1 and percentage of aflatoxin excreted in milk in ewes fed a single oral dose $(2 \mathrm{mg})$ of AFB1.

\begin{tabular}{lccccc}
\hline & Ewe 1 & Ewe 2 & Ewe 3 & Ewe 4 & Mean \\
\hline AFB1/kg of BW, $\mu \mathrm{g}$ & 41.84 & 42.83 & 43.76 & 59.35 & 46.95 \\
Total milk yield in 96 h, kg & 4.066 & 5.212 & 5.252 & 4.560 & 4.772 \\
Total output of toxin (AFM1), $\mu \mathrm{g}$ & 0.288 & 0.865 & 0.982 & 0.432 & 0.642 \\
Output of AFM1 at 12 h, \% & 54.38 & 47.10 & 29.17 & 77.34 & 52.00 \\
Output of AFM1 at 24 h, \% & 77.48 & 62.89 & 57.96 & 84.31 & 70.66 \\
AFM1/AFB1, \% & 0.014 & 0.043 & 0.049 & 0.022 & 0.032 \\
\hline
\end{tabular}

at $72 \mathrm{~h}$ post withdrawal ( $384 \mathrm{~h}$ after the first administration).

Values of AFM1 concentration above the EC tolerance level $(0.05 \mu \mathrm{g} / \mathrm{kg})$ were detected in $\mathrm{T} 2$ and $\mathrm{T} 3$ groups after the first milking. However, group T1 also reached values of AFM1 above the EC tolerance level at $144 \mathrm{~h}(0.057 \mu \mathrm{g} / \mathrm{kg})$. High-producing ewes are often fed concentrate doses up to 0.8 to $1.0 \mathrm{~kg} / \mathrm{d}$ per head. Therefore, if the contamination level of concentrate with AFB1 is close the EC tolerance level $(50 \mu \mathrm{g} / \mathrm{kg})$, the intake of toxin by ewes may be higher than the dose administered in our experiment to the T1 group (32 $\mu \mathrm{g} /$ d per head). Similarly, the EC tolerance level of AFM1 in the milk of dairy cows could be exceeded with intake of feed naturally contaminated by AFB1 at concentrations of $48 \mu \mathrm{g} / \mathrm{kg}$ (Frobish et al., 1986).

The steady-state condition was reached at 216 to 312 $\mathrm{h}$ in the present study, so later than in cows, where it was reached after $24 \mathrm{~h}$ (Frobish et al., 1986) and $76 \mathrm{~h}$ (Polan et al., 1974) from the first intake of toxin. Another difference between our experiment on sheep and the results reported in literature for cows is related to the excretion pattern of AFM1 in milk. In dairy cows the plateau started in correspondence to the highest concentration of AFM1 (Polan et al., 1974; Frobish et al., 1986), while in our experiment, this happened at concentrations lower than the observed maximum.

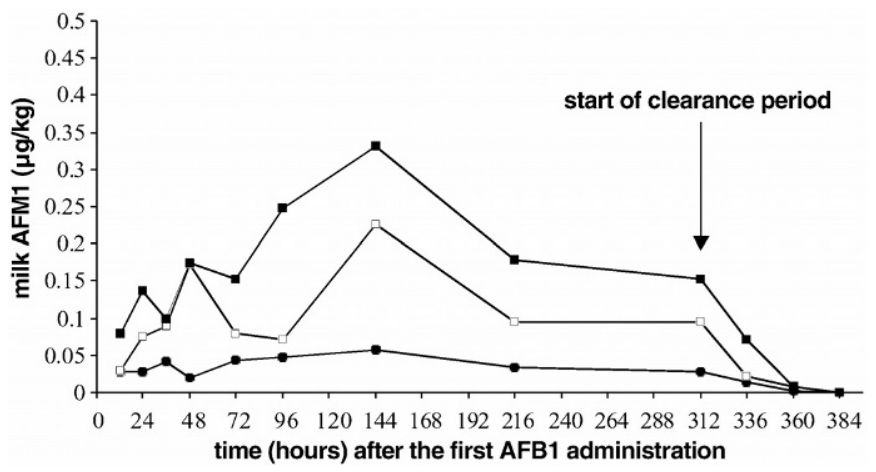

Figure 3. AFM1 concentrations in the milk of ewes fed $32(\mathbf{)})$, 64 ( $\square$ ) and 128 (ם) $\mu \mathrm{g}$ of AFB1 per day. For each treatment, each data point represent the mean of four animals.
The time at which AFM1 was no longer detectable in milk was not related to the AFB1 dose or to the concentration of AFM1 before the withdrawal of contaminated feed, as already observed in cows (Frobish et al., 1986). Indeed, in all treated groups, the AFM1 went down to zero at $384 \mathrm{~h}$ after the first administration.

The relationship between milk AFM1 concentration and AFB1 intake, calculated using the concentrations at 216 and $312 \mathrm{~h}$, can be expressed by the equation:

$$
\begin{gathered}
\operatorname{AFM} 1(\mu \mathrm{g} / \mathrm{kg})=-0.0043+0.00136 \operatorname{AFB} 1(\mu \mathrm{g} / \mathrm{d}) \\
\mathrm{SE}=0.031 ; \mathrm{R}^{2}=0.77 ; P<0.001
\end{gathered}
$$

Therefore, AFM1 concentration increased linearly as AFB1 intake increased. The intercept was not different from zero $(P=0.752)$. This equation suggests that ewes fed rations contaminated with AFB1 below the EC tolerance level $(0.05 \mathrm{mg} / \mathrm{kg})$ may produce milk containing AFM1 concentrations above EC limit $(0.05 \mu \mathrm{g} / \mathrm{kg})$. A similar remark was reported by Veldman et al. (1992) and by Munksgaard et al. (1987) for dairy cattle fed naturally contaminated feeds.

The concentration of AFM1 in milk was significantly influenced by the treatments, whereas the carryover was not associated to AFB1 intake (Table 2), as pre-

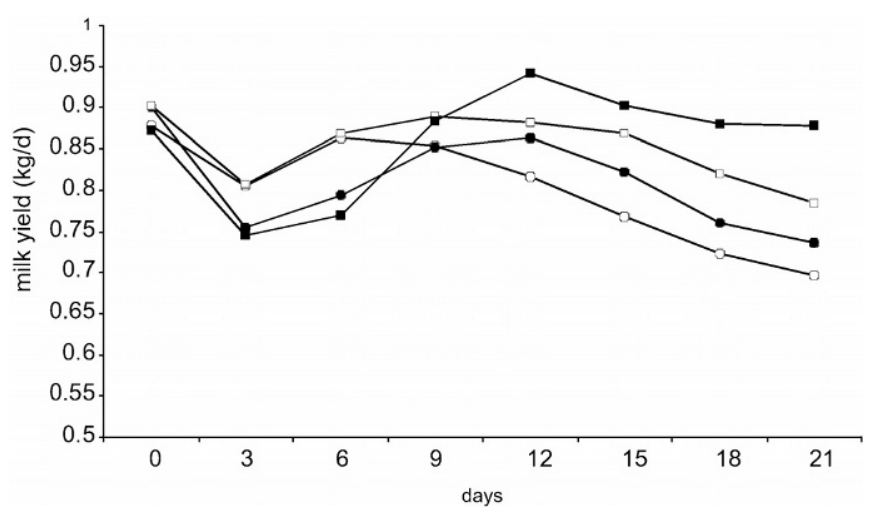

Figure 4. Milk production of ewes fed $0(\bigcirc), 32(\bullet), 64(\square)$, and $128(\square) \mu \mathrm{g}$ of AFB1 per day. Each data point represents the mean of three days of measurements for each group. 
Table 2. Least square means of concentration, excretion, and carryover of AFM1 in milk, at 216 and 312 $\mathrm{h}$ after the first dose was supplied, in experimental groups that received different daily doses of AFB1 (32, 64 and $128 \mu \mathrm{g}$ in T1, T2, and T3, respectively).

\begin{tabular}{llllllll}
\hline & & & & & \multicolumn{3}{c}{ Effect $^{1}(P)$} \\
\cline { 6 - 8 } Variable & T1 & T2 & T3 & SE & Treatment & Time & Interaction \\
\hline AFB1/d per kg of BW, $\mu \mathrm{g}$ & 0.767 & 1.597 & 3.308 & 0.048 & $* *$ & $\mathrm{NS}$ & $\mathrm{NS}$ \\
Milk yield, kg & 0.426 & 0.447 & 0.451 & 0.024 & $\mathrm{NS}$ & $\mathrm{NS}$ & $\mathrm{NS}$ \\
AFM1, $\mu \mathrm{g} / \mathrm{kg}$ of milk & 0.031 & 0.095 & 0.166 & 0.006 & $* *$ & $\mathrm{NS}$ & $\mathrm{NS}$ \\
AFM1, $\mu \mathrm{g}$ & 0.013 & 0.042 & 0.076 & 0.005 & $* *$ & $\mathrm{NS}$ & $\mathrm{NS}$ \\
Carryover, \% & 0.082 & 0.133 & 0.119 & 0.011 & $\mathrm{NS}$ & $\mathrm{NS}$ & $\mathrm{NS}$ \\
\hline${ }^{1} \mathrm{NS}=$ not significant $(P>0.05)$. & & & & & & \\
$* * P<0.01$. & & & & & &
\end{tabular}

viously observed in cows (Frobish et al., 1986; Veldman et al., 1992). This suggests that, at least in range of intake from 32 to $128 \mu \mathrm{g}$ AFB1 per day, the liver activity in the conversion of AFB1 in AFM1 was not a rate limiting step, in accordance with the results of Veldman et al. (1992) for dairy cows. The effect of time and the treatment $\times$ time interaction did not differ for any variable considered. The average carryover observed in our experiment $(0.112 \%)$ was lower than that reported for goats $(0.397 \%$; Nageswara Rao and Chopra, 2001) that received feed artificially contaminated with AFB1 doses similar to those used in the T3 group. In cow milk, the carryover ranged from 0.01 to $6.6 \%$ (Polan et al., 1974; Patterson et al., 1980; Price et al., 1985; Frobish et al., 1986; Munksgaard et al., 1987; Fremy et al., 1988; Veldman et al., 1992).

The extensive variability in the expression and catalytic activity of hepatic enzyme families (e.g., cytochrome P450 and glutathione-transferase) involved in the biotransformation and detoxification of AFB1 is considered the main cause of the observed difference among species in the susceptibility to the toxic effects of aflatoxin (Pier, 1992; Guerre et al., 1996). This may also explain the different carryover of AFB1 found among species.

Milk yield was lower $(P<0.05)$ in $\mathrm{C}$ and $\mathrm{T} 1$ groups in comparison to T2 and T3 groups (Table 3). The effect of the treatments on milk yield over time is reported in detail in Figure 4, and the data were presented as the mean of $3 \mathrm{~d}$ of measurements for each group. Before the beginning of the AFB1 administration $(0 \mathrm{~d})$, the four groups of animals had similar production levels. During the intoxication period, the lactation curve of the control and of the treated groups did not show a definite trend until the 9 th day of the experiment. After $12 \mathrm{~d}$ the lactation curves were different for all groups with the milk yield that increased proportionally to AFB1 doses. This trend was maintained in the clearance period (21st day of the experiment). In dairy cows Polan et al. (1974) found that milk production was to- tally unaffected by level of AFB1 consumption (1.6 to $20 \mu \mathrm{g}$ of AFB1 per kilogram of BW). Fat, protein, and lactose concentrations (Table 3 ) did not vary with treatments. These results may be due to the effect of the modifications caused by AFB1 on rumen fermentations, on the digestive tract adsorption or on hepatic metabolism. Rizzi et al. (1995) observed a positive effect of the AFB1 on cellulose and NDF digestibility in lambs which received daily doses of $80 \mu \mathrm{g}$ of AFB1 per kilogram of BW for $21 \mathrm{~d}$. These results suggest that further investigations are necessary to clarify the reasons for the increase of the milk production (our experiment) and of digestibility (Rizzi et al., 1995) observed in animals that received low doses of aflatoxin. The SCC was not influenced by AF intake, as previously observed in cows (Applebaum et al., 1982), and was under the threshold $(300,000 / \mathrm{ml})$ reported for subclinical mastitis in dairy ewes for all groups (Ranucci and Morgante, 1994). The treatment $\times$ time interaction was not significant for any variable analyzed.

The BW increased $(P<0.01)$ from the beginning $(40.2$ $\pm 3.58 \mathrm{~kg})$ to the end $(45.0 \pm 3.69 \mathrm{~kg})$ of the experimental period, but it was not affected by the treatments. The increase in BW was likely a consequence of the level of concentrate fed in the current study.

The results of the analysis of variance on serum parameters (Table 4) revealed an influence of aflatoxin treatments only on GPT and ALP $(P<0.001)$. The treatment $\times$ time interaction was not significant for any of the variables analyzed. The covariate was significant for ALP, total protein, urea, and cholesterol. The GPT activity was significantly higher in T3 compared with $\mathrm{C}, \mathrm{T} 1$, and $\mathrm{T} 2$ groups in the second week of intoxication period. During the clearance period (3rd week), when AFB1 was withdrawn from the diet, the GPT value in T3 group decreased to the level of the others experimental groups. The ALP concentration did not vary in the 2 wk of the intoxication period between the control and the treated groups. During the clearance period, the 
Table 3. Least-square means of daily milk yield and composition of the experimental groups that received different daily doses of AFB1 $(0,32,64$, and $128 \mu \mathrm{g} / \mathrm{d}$ in C, T1, T2 and T3, respectively).

\begin{tabular}{|c|c|c|c|c|c|c|c|c|}
\hline \multirow[b]{2}{*}{ Variable } & \multirow[b]{2}{*}{$\mathrm{C}$} & \multirow[b]{2}{*}{$\mathrm{T} 1$} & \multirow[b]{2}{*}{$\mathrm{T} 2$} & \multirow[b]{2}{*}{ T3 } & \multirow[b]{2}{*}{$\mathrm{SE}$} & \multicolumn{3}{|c|}{ Effect $^{1}(P)$} \\
\hline & & & & & & Treatment & Time & Interaction \\
\hline Milk, kg/d & $0.815^{\mathrm{a}}$ & $0.821^{\mathrm{a}}$ & $0.855^{\mathrm{b}}$ & $0.863^{b}$ & 0.014 & $*$ & $* *$ & NS \\
\hline Fat, \% & 7.37 & 7.12 & 6.99 & 7.57 & 0.623 & NS & $* *$ & NS \\
\hline Protein, \% & 5.98 & 6.02 & 5.82 & 5.68 & 0.462 & NS & NS & NS \\
\hline Lactose, \% & 4.58 & 4.63 & 4.61 & 4.66 & 0.183 & NS & ** & NS \\
\hline SCC, ln & 5.02 & 5.31 & 4.79 & 4.94 & 0.885 & NS & NS & NS \\
\hline TMC, $\times 10^{3} / \mathrm{ml}$ & 69 & 48 & 78 & 55 & 58.32 & NS & * & NS \\
\hline
\end{tabular}

${ }^{\mathrm{a}, \mathrm{b}}$ Means within a row with different superscripts differ $(P<0.05)$

${ }^{1} \mathrm{NS}=$ not significant $(P>0.05)$.

$* P<0.05$.

$* * P<0.01$.

ALP showed the lowest value in T3 and the highest value in T2 groups $(P<0.01)$, while in $\mathrm{C}$ and $\mathrm{T} 1$ groups it had intermediate values. Serum enzyme activities are generally elevated in aflatoxicosis, indicating hepatocyte damage (Pier, 1992). No significant differences were observed for the other hepatic enzyme activity (GOT), suggesting that the levels of AFB1 in this trial caused only a low and transient negative effect on hepatocytes. In lambs, a transient alteration of enzymatic activities was reported (Edrington et al., 1994) with higher $\mathrm{AF}$ doses (3.85 to $5.42 \mathrm{mg} / \mathrm{d}$ ) and a longer period of AF administration than those used in our experiment.

No effects due to aflatoxin were observed for all hematological parameters considered (Table 5). This is in agreement with the results found in a previous study (Fernandez et al., 2000) on lambs that received high doses of aflatoxin ( $2 \mathrm{mg}$ of aflatoxin/ $\mathrm{kg}$ of diet).

Table 4. Least square means of serum parameters of experimental groups that received different daily doses of $\operatorname{AFB} 1(0,32,64$, and $128 \mu \mathrm{g}$ in $\mathrm{C}, \mathrm{T} 1, \mathrm{~T} 2$, and $\mathrm{T} 3$, respectively).

\begin{tabular}{|c|c|c|c|c|c|c|}
\hline \multirow[b]{2}{*}{ Item $^{1}$ and week ${ }^{2}$} & & \multicolumn{4}{|c|}{ Groups } & \multirow[b]{2}{*}{$\mathrm{SE}$} \\
\hline & & $\mathrm{C}$ & $\mathrm{T} 1$ & $\mathrm{~T} 2$ & T3 & \\
\hline \multirow[t]{3}{*}{ GOT, IU/L } & 1 & 165.57 & 131.93 & 163.04 & 185.29 & \multirow{3}{*}{29.53} \\
\hline & 2 & 48.37 & 40.51 & 49.06 & 41.70 & \\
\hline & 3 & 62.90 & 59.79 & 61.37 & 71.09 & \\
\hline \multirow{3}{*}{ GPT, IU/L } & 1 & 23.89 & 18.39 & 23.21 & 24.21 & \multirow{3}{*}{5.49} \\
\hline & 2 & $4.65^{\mathrm{A}}$ & $4.61^{\mathrm{A}}$ & $4.68^{\mathrm{A}}$ & $21.59^{\mathrm{B}}$ & \\
\hline & 3 & 5.28 & 6.08 & 8.19 & 14.67 & \\
\hline \multirow[t]{3}{*}{ ALP, IU/L* } & 1 & 68.94 & 85.70 & 70.41 & 67.76 & \multirow[t]{3}{*}{30.00} \\
\hline & 2 & 87.68 & 80.61 & 90.81 & 79.21 & \\
\hline & 3 & $98.85^{\mathrm{AB}}$ & $94.40^{\mathrm{AB}}$ & $151.41^{\mathrm{A}}$ & $49.48^{\mathrm{B}}$ & \\
\hline \multirow[t]{3}{*}{ Glucose, mg/dl } & 1 & 63.94 & 63.54 & 65.07 & 60.26 & \multirow[t]{3}{*}{4.81} \\
\hline & 2 & 64.44 & 59.02 & 61.76 & 64.35 & \\
\hline & 3 & 52.62 & 52.92 & 56.85 & 55.77 & \\
\hline \multirow[t]{3}{*}{ Total Protein, g/dl } & 1 & 7.39 & 7.11 & 7.08 & 7.42 & \multirow[t]{3}{*}{0.42} \\
\hline & 2 & 7.59 & 7.74 & 7.76 & 7.62 & \\
\hline & 3 & 7.46 & 7.64 & 7.49 & 7.33 & \\
\hline \multirow{3}{*}{ Urea, mg/dl ${ }^{3}$} & 1 & 46.93 & 42.08 & 47.00 & 41.00 & \multirow[t]{3}{*}{5.19} \\
\hline & 2 & 41.23 & 36.86 & 40.52 & 36.98 & \\
\hline & 3 & 43.77 & 43.80 & 42.12 & 40.52 & \\
\hline \multirow[t]{3}{*}{ Cholesterol, mg/dl* } & 1 & 68.91 & 66.17 & 47.31 & 68.68 & \multirow[t]{3}{*}{13.30} \\
\hline & 2 & 69.40 & 73.84 & 90.56 & 73.98 & \\
\hline & 3 & 66.94 & 72.73 & 76.58 & 81.92 & \\
\hline
\end{tabular}


Table 5. Least square means of haematological parameters of experimental groups that received different daily doses of $\operatorname{AFB} 1(0,32,64$, and $128 \mu \mathrm{g}$ in $\mathrm{C}$, T1, T2, and T3, respectively).

\begin{tabular}{|c|c|c|c|c|c|c|}
\hline \multirow[b]{2}{*}{ Item $^{1}$ and week ${ }^{2}$} & & \multicolumn{4}{|c|}{ Groups } & \multirow[b]{2}{*}{$\mathrm{SE}$} \\
\hline & & $\mathrm{C}$ & $\mathrm{T} 1$ & $\mathrm{~T} 2$ & $\mathrm{~T} 3$ & \\
\hline \multirow[t]{3}{*}{$\mathrm{WBC} \times 10^{3} \mathrm{cells} / \mu \mathrm{l}^{*}$} & 1 & 7.69 & 8.03 & 8.39 & 9.26 & \multirow[t]{3}{*}{0.80} \\
\hline & 2 & 9.15 & 7.48 & 8.52 & 7.11 & \\
\hline & 3 & 7.46 & 8.38 & 8.29 & 7.66 & \\
\hline \multirow[t]{3}{*}{$\mathrm{RBC} \times 10^{6} \mathrm{cells} / \mu \mathrm{l}^{*}$} & 1 & 8.76 & 9.61 & 8.20 & 9.71 & \multirow[t]{3}{*}{0.64} \\
\hline & 2 & 11.00 & 10.34 & 10.85 & 10.24 & \\
\hline & 3 & 9.93 & 9.98 & 9.85 & 9.91 & \\
\hline \multirow[t]{3}{*}{$\mathrm{HGB}, \mathrm{g} / \mathrm{dl} \mathbf{l}^{*}$} & 1 & 8.29 & 9.12 & 8.09 & 9.12 & \multirow[t]{3}{*}{0.5} \\
\hline & 2 & 10.92 & 10.33 & 10.75 & 10.34 & \\
\hline & 3 & 9.80 & 9.92 & 9.86 & 10.07 & \\
\hline \multirow[t]{3}{*}{$\mathrm{HCT}, \%$} & 1 & 29.90 & 32.87 & 28.30 & 33.30 & \multirow[t]{3}{*}{2.22} \\
\hline & 2 & 38.67 & 36.78 & 38.61 & 36.97 & \\
\hline & 3 & 35.45 & 35.75 & 35.18 & 35.92 & \\
\hline \multirow[t]{3}{*}{ MCHC, g/dl } & 1 & 27.96 & 27.71 & 28.68 & 27.57 & \multirow[t]{3}{*}{0.55} \\
\hline & 2 & 28.10 & 27.86 & 27.71 & 27.76 & \\
\hline & 3 & 27.93 & 27.81 & 27.92 & 28.00 & \\
\hline \multirow[t]{3}{*}{$\mathrm{MCH}, \mathrm{pg}$} & 1 & 9.64 & 9.56 & 9.86 & 9.36 & \multirow[t]{3}{*}{0.30} \\
\hline & 2 & 9.95 & 10.04 & 9.72 & 10.11 & \\
\hline & 3 & 9.95 & 9.99 & 9.99 & 10.13 & \\
\hline \multirow[t]{3}{*}{$\mathrm{MCV}, \mu \mathrm{l}$} & 1 & 34.39 & 35.40 & 34.52 & 34.04 & \multirow[t]{3}{*}{0.41} \\
\hline & 2 & 35.63 & 35.95 & 35.77 & 36.07 & \\
\hline & 3 & 35.79 & 35.85 & 35.54 & 35.81 & \\
\hline
\end{tabular}

${ }^{1} \mathrm{WBC}=$ white blood cell count; $\mathrm{RBC}=$ red blood cell count; HGB = hemoglobin; $\mathrm{HCT}$ = hematocrit; $\mathrm{MCHC}=$ mean corpuscular hemoglobin concentration; $\mathrm{MCH}=$ mean corpuscular hemoglobin; $\mathrm{MCV}=$ mean corpuscular volume.

${ }^{2} \mathrm{AFB} 1$ was withdrawn after wk 2 .

*Treatment $\times$ week interaction $(P<0.05)$.

\section{CONCLUSIONS}

The administration of a single dose of AFB1 to lactating dairy ewes showed that total AFM1 excretion in milk is lower than that observed for the dairy cows. The excretion of the AFM1 in milk followed an exponential decreasing pattern with high variability among animals.

The continuous administration of AFB1 for $14 \mathrm{~d}$ in different doses showed that the milk AFM1 concentration was significantly affected by the AFB1 dose, whereas the carryover was not significantly affected.

In practice, the administration to lactating dairy ewes of feeds contaminated with AFB1 under the threshold admitted by the EC can involve the production of milk with a content of AFM1 above the threshold allowed by EC.

\section{ACKNOWLEDGMENTS}

This research was supported by the Consiglio Nazionale delle Ricerche (Agenzia 2000 program) and by the Ministero dell'Istruzione, dell'Università e della Ricerca and Ministero delle Politiche Agricole e Forestali (SISPROLAT project). The authors gratefully acknowledge the contributions of M. Palomba, R. Rubattu, F. Porcu and P. Sechi for the assistance in the chemical analyses.

\section{REFERENCES}

Allcroft, R., and B. A. Roberts. 1968. Toxic groundnut meal: The relationship between aflatoxin B1 intake by cows and excretion of aflatoxin M1 in milk. Vet. Rec. 82:116-118.

Applebaum, R. S., R. E. Brackett, D. W. Wiseman, and E. H. Marth. 1982. Responses of dairy cows to dietary aflatoxin: Feed intake and yield, toxin content, and quality of milk of cows treated with pure and impure aflatoxin. J. Dairy Sci. 65:1503-1508.

Armbrecht, B., W. T. Shalkop, L. D. Rollins, A. E. Pohland, and L. Stoloff. 1970. Acute toxicity of aflatoxin B1 in wethers. Nature 225:1062-1063.

Commission of the European Communities. 2001. Commission Regulation (EC) N. 466/2001 of 8 March 2001 setting maximum levels for certain contaminants in foodstuffs (Text with EEA relevance). Official J. Eur. Communit. L77:1-13.

Council of the European Union. 1986. Council Directive 86/609/EEC of 24 November 1986 on the approximation of laws, regulations and administrative provisions of the Member States regarding the protection of animals used for experimental and other scientific purposes. Official J. Eur. Communit. L358:1-28.

Council of the European Union. 1999. Council Directive 1999/29/EC of 22 April 1999 on the undesirable substances and products in animal nutrition. Official J. Eur. Communit. L115:32-46.

Edrington, T. S., R. B. Harvey, and L. F. Kubena. 1994. Effect of aflatoxin in growing lambs fed ruminally degradable or escape protein sources. J. Anim. Sci. 72:1274-1281.

Fernandez, A., M. Hernandez, M. T. Verde, and M. Sanz. 2000. Effect of aflatoxin on performance, hematology, and clinical immunology in lambs. Can. J. Vet. Res. 64:53-58.

Fremy, J. M., J. P. Gautier, M. P. Herry, C. Terrier, and C. Calet. 1988. Effects of ammoniation on the carryover of aflatoxins into bovine milk. Food Addit. Contam. 5:39-44.

Frobish, R. A., D. D. Bradley, D. D. Wagner, P. E. Long-Bradley, and H. Hairston. 1986. Aflatoxin residues in milk of dairy cows after 
ingestion of naturally contaminated grain. J. Food Prot. 49:781-785.

Guerre, P., P. Galtier, and V. Burgat 1996. Le métabolisme: Un facteur de susceptibilité à la toxicité des aflatoxines. Rev. Med. Vet. 147:879-892.

IARC. 1993. IARC Monographs on the evaluation of carcinogenic risks to human. Vol. 56. Some naturally occurring substances: food items and constituents, heterocyclic aromatic amines and mycotoxins. International Agency for Research on Cancer, Lione.

Kiermeier, F., and M. Buchner. 1977. On the Aflatoxin M1 content of the cheese during ripening and storage. Z. Lebensm. Unters.Forsch. 164:87-91.

Minervini, F., L. Monaci, M. T. Montagna, I. Dragoni, and A. Visconti. 2000. On the occurrence of aflatoxin $\mathrm{M}$ and toxigenic fungi in sheep and goat dairy products collected from southern Italy. Pages 145-148 in Proc.14th Natl. Congr. Società Italiana di Patologia e Allevamento degli Ovini e dei Caprini. Vietri sul Mare, Salerno, Italy.

Munksgaard, L., J. Larsen, H. Werner, P. E. Andersen, and B. T. Viuf. 1987. Carry over of aflatoxin from cows' feed to milk and milk products. Milchwissenschaft 42:165-167.

Nabney, J., M. B. Burbage, R. Allcroft, and G. Lewis. 1967. Metabolism of aflatoxin in sheep: Excretion pattern in the lactating ewe. Food Cosmet. Toxicol. 5:11-17.

Nageswara Rao, S. B., and R. C. Chopra. 2001. Influence od sodium bentonite and activated charcoal on aflatoxin M1 excretion in milk of goats. Small Rumin. Res. 41:203-213.

Patterson, D. S. P., E. M. Glancy, and B. A. Roberts. 1980. The carry over of AFM1 in to the milk of cows fed ration containing a low concentration of AFB1. Food Cosm. Toxicol. 18:35-37.
Pier, A. C. 1992. Major biological consequences of aflatoxicosis in animal production. J. Anim. Sci. 70:3964-3967.

Polan, C. E., J. R. Hayes, and T. C. Campbell. 1974. Consumption and fate of aflatoxin B1 by lactacting cows. J. Agric. Food Chem. 22:635-638.

Price, R. L., J. H. Paulson, O. G. Lough, C. Gingg, and A. G. Kurtz. 1985. Aflatoxin conversion by dairy cattle consuming naturallycontaminated whole cottonseed. J. Food Prot. 48:11-15.

Pulina, G., and R. Furesi. 2001. L'allevamento e la produzione di latte ovino in Italia. Scienza e Tecnica Lattiero-Casearia 52:209-216.

Ranucci, S., and M. Morgante. 1994. Sanitary control of the sheep udder: total and differential cell counts in milk. Pages 5-16 in Proc. International Symposium on Somatic Cells and Milk of Small Ruminants. Bella, Potenza, Italy. R. Rubino, ed. Europa, Potenza, Italy.

Rizzi, L., L. Lambertini, L. Marchesini, and A. Gramenzi. 1995. Effects of aflatoxin B1 and alluminosilicate on in vivo digestibility in lambs. Pages 839-840 in Proc. 49th Natl. Congr. Società Italiana delle Scienze Veterinarie. Salsomaggiore Terme, Italy.

Sabbioni, G., and O. Sepai. 1998. Determination of human exposure to aflatoxins. Pages 183-226 in Mycotoxins in Agriculture and Food Safety. K. K. Sinha and D. Bhatnagar, ed. Marcel Dekker Inc., New York.

Trucksess, M. W., J. L. Richard, L. Stoloff, J. S. Mcdonald, and W. C. Brumley. 1983. Absorption and distribution patterns of aflatoxicol and aflatoxins B1 and M1 in blood and milk of cows given aflatoxin B1. Am. J. Vet. Res. 44:1753-1756.

Veldman, A., J. A. C. Meijs, G. J. Borggreve, and J. J. Heeres-van der Tol. 1992. Carryover of aflatoxin from cows' food to milk. Anim. Prod. 55:163-168. 